\title{
水の酸化分子触媒の新展開
}

\section{New Development of molecular catalysts for water oxidation}

\author{
新潟大学大学院自然科学研究科・科学技術振興機構 八木 政行 * \\ Department of Materials Science and Technology, Faculty of Engineering, Niigata University \\ Masayuki Yagi* \\ Received February 14, 2011; E-mail: yagi@eng.niigata-u.ac.jp
}

\begin{abstract}
Artificial photosynthesis is expected as one of promising clean energy-providing systems in future. Development of an efficient catalyst for water oxidation to evolve $\mathrm{O}_{2}$ is a key task to yield a breakthrough for construction of an artificial photosynthetic device. Recently, significant progress has been reported in development of the molecular catalysts for water oxidation based on manganese, ruthenium and iridium complexes. The molecular aspects of the catalysts in chemical, electrochemical, and photo- or photoelectro-driven water oxidation were reviewed to provide hints to design an efficient catalyst. This review will mainly cover the related progress in the last 5 or 6 years.
\end{abstract}

\section{1.はじめに}

近年、エネルギー・環境問題を背景に人工光合成の開 発に大きな関心が寄せられている。人工光合成では、太 陽光エネルギーを利用して水素、蟻酸、メタノールのよ うな高エネルギー（還元力を有する）有用化合物を生成 することにより、光一化学エネルギー変換が達成され る。ここで重要なことは、高エネルギー有用化合物の生 成に必要な電子をどのように獲得するかである。植物の 光合成では、水が電子源となり炭水化物が産生されてい る。四核マンガンオキソクラスターを活性中心 (oxygen evolving complex; OEC）とする蛋白の酵素反応により水 が酸化され、((1) 式) 電子が光合成系に供給される ${ }^{1-6)}$ 。

$$
2 \mathrm{H}_{2} \mathrm{O} \rightarrow \mathrm{O}_{2}+4 \mathrm{H}^{+}+4 \mathrm{e}^{-}
$$

水は安価で地球上に豊富であるだけでなく、酸化生成 物はクリーンな酸素分子であるため、電子源としては最 適な化合物である。人工光合成を将来のエネルギー基盤 の一つと位置づけるためには、水を電子源として利用す ることが不可欠である。水の酸化能を有する高活性かつ 安定な水の酸化触媒の開発は、人工光合成の構築に向け 最も重要な研究課題の一つである ${ }^{7-14)}$

連絡先著者名: 八木 政行

連絡先 : 950-2181 新潟市西区五十風二の町 8050

新潟大学工学部 機能材料工学科

Tel: 025-262-6790 Fax: 025-262-6790

Corresponding Author: Masayuki Yagi

Address: 8050 Ikarashi-2, Niigata 950-2181, Japan.

Keywords:photosynthesis, oxygen evolving complex, artificial photosynthesis, water oxidation, $\mathrm{O}_{2}$ evolution, molecular catalyst,
1973 年石油輸出国機構が発表した石油価格の引き 上げに端を発した、いわゆる第一次オイルショックを 契機に、水の酸化触媒能を有する金属錯体は 1980 年 代に勢力的に研究され、いくつかの先導的な研究が 発表された。その中でも、Meyerらにより報告され た"blue dimer”と呼ばれる $\left[\text { cis,cis- }\left\{\mathrm{Ru}(\mathrm{bpy})_{2}(\mathrm{OH})\right\}_{2} \mathrm{O}\right]^{4+}$ (bpy = 2,2'-bipyridine) 錯体は大きな関心を集めた ${ }^{15-17) 。 ~}$ それ以降、水の酸化触媒の研究は一旦落ち着きを見せた が、1997年 12 月に開催された地球温暖化防止京都会議 で採択された京都議定書をはじめ環境問題の深刻化とと もに、水の酸化触媒の研究に再び大きな関心が寄せられ ている。最近、特にマンガン錯体、ルテニウム錯体、イ リジウム錯体およびポリオキソメタレート錯体などの水 の酸化触媒の研究が活発に展開されている。本総説は、 最近 5、6 年の水の酸化能を有する錯体触媒に関する主 な研究例を紹介し、将来の錯体触媒の設計・開発を展望 する。最近の研究進展を包括的に理解するために、過去 10 年ほどの関連した研究例も一部簡単に紹介する。本 総説で対照とした期間以前の研究については、他の文献 を参照されたい ${ }^{10-14)}$ 。

\section{2. マンガン錯体}

これまで多くのマンガン錯体が合成され、OEC の構 造に関する多くの知見を与えてきたが、実際に水の酸化 触媒能を有するマンガンオキソ錯体の報告例は非常に少 ない。Brudvig らは $\left[\left(\mathrm{H}_{2} \mathrm{O}\right)(\text { tpy }) \mathrm{Mn}(\mu-\mathrm{O})_{2} \mathrm{Mn}(\mathrm{tpy})\left(\mathrm{H}_{2} \mathrm{O}\right)\right]^{3+}$ (tpy $=2,2^{\prime}: 6$ ', 2”-terpyridine) (以下、Mn-dimer と略す。) 錯体と次亜塩素酸ナトリウムやオキソン (ペルオキソ一 硫酸カリウム）のような酸素原子供与剤との水溶液中 
での反応で酸素発生を報告した ${ }^{18,19)}$ 。Mn-dimer の夕ー ンオーバー数（TN）は、反応時間 6 時間で 4 回であっ $た^{18)}$ 。酸素原子供与剤の代わりに一電子酸化剤である $\mathrm{Ce}^{\mathrm{IV}}$ イオンを用いたとき酸素発生が確認されたが、Mndimerの TN は 0.54 回 $\left(250 \mu \mathrm{M}\right.$ Mn-dimer、30 mM Ce $\left.{ }^{\mathrm{IV}}\right)$ であった ${ }^{20)}$ 。しかし、 $\mathrm{Ce}^{\mathrm{IV}}$ 酸化剂を用いた同様の実験が 他のいくつかの研究グループで実施されたが、酸素発生

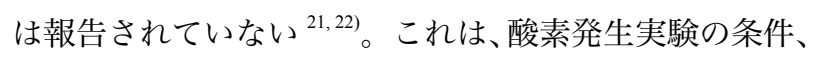
あるいは酸素分析の限界レベルの相違と考えられるが、 $\mathrm{Ce}^{\mathrm{IV}}$ 酸化剂を用いたとき $\mathrm{Mn}$-dimer が触媒として機能し ていない点は関連研究すべてで一致している。これらの 結果は、 $\mathrm{Ce}^{\mathrm{IV}}$ のような電子酸化剂は Mn-dimerによる水 の酸化に有効ではないことを示すが、これは Mn-dimer による触媒サイクルの初期過程で酸素原子供与剂から Mn-dimer への酸素原子移動を伴うためと考えられる。

カオリン、モンモリロナイトおよびマイカのような層 状化合物に Mn-dimer を吸着させた懸濁系で水の酸化が 研究された。C $\mathrm{C}^{\mathrm{IV}}$ 酸化剂と Mn-dimer 吸着層状化合物を 混合したとき、水から酸素が発生することが報告され た $^{21,23,24)}$ 。マイカまたはカオリンに吸着したときの Mndimerの TN はそれぞれ 15 または 18 回であった。この 結果より、Mn-dimer 錯体が層状化合物上で水の酸化触 媒として働くことが示された。酸素発生の速度解析より、 Mn-dimer 錯体二分子が協同的に水の酸化触媒として働 くことが示唆された。層状化合物に吸着することによ り、均一水溶液系で優先的に進行する過マンガン酸イオ ンへの分解が抑制されるだけでなく、二分子の協同触媒 作用が助長されたため、水の酸化触媒として働いたと考 えられる。最近、Mn-dimer を OEC モデル、 $\left[\mathrm{Ru}(\mathrm{bpy})_{3}\right]^{2+}$ (bpy $=2,2$ '-bypiridine) を光励起中心としてそれぞれマイ 力層間に挿入した光合成 PSII モデルの研究が報告され た (Fig. 1) ${ }^{25)}$ 。電子アクセプターである $15 \mathrm{mM} \mathrm{Na}_{2} \mathrm{~S}_{2} \mathrm{O}_{8}$ を含む水溶液に Mn-dimer $(1.6 \mu \mathrm{mol})$ および $\left[\mathrm{Ru}(\mathrm{bpy})_{3}\right]^{2+}$ $(0.25 \mu \mathrm{mol})$ を吸着したマイカ $(10 \mathrm{mg})$ を懸濁させ、可視 光照射 $(\lambda>420 \mathrm{~nm})$ を行ったところ、5.5 $\mu \mathrm{mol}$ の酸素が 発生した。Mn-dimer および $\left[\mathrm{Ru}(\mathrm{bpy})_{3}\right]^{2+}$ の TN はそれぞ れ、3.4および 88 回であった。 $\left[\mathrm{Ru}(\mathrm{bpy})_{3}\right]^{2+}$ なして、
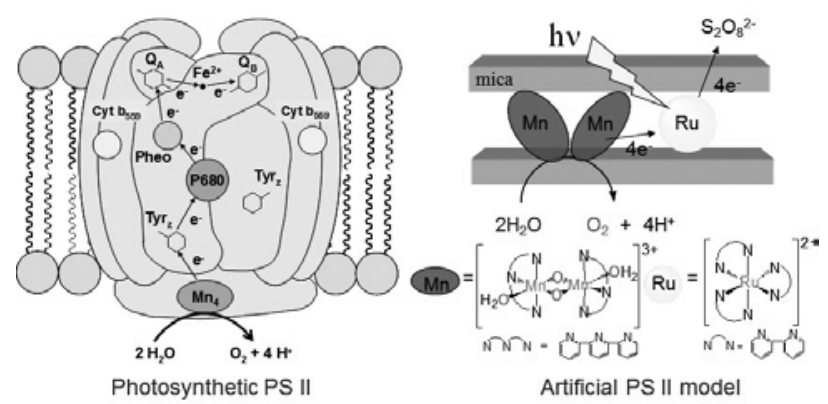

Fig. 1 Illustration of photosynthetic PSII and an artificial PSII model using Mn and Ru complexes as an OEC and photoexcitation center models.
Mn-dimer から外部電子アクセプターである $\mathrm{S}_{2} \mathrm{O}_{8}{ }^{2-}$ への 光誘起電子移動が達成され、Mn-dimer 末端で水が酸化 され、酸素が発生したと推定された（Fig. 1)。

$\mathrm{Mn}_{4} \mathrm{O}_{4}\left(2 \mathrm{Mn}^{\mathrm{III}}, 2 \mathrm{Mn}^{\mathrm{IV}}\right)$ 核を有する $\mathrm{L}_{6} \mathrm{Mn}_{4} \mathrm{O}_{4}\left(\mathrm{~L}^{-}=\right.$ diphenylphosphinate), 錯体が合成され 26) $\mathrm{Mn}_{4} \mathrm{O}_{4}$ 核オキ ソの反応性が研究された。 $\mathrm{L}_{6} \mathrm{Mn}_{4} \mathrm{O}_{4}$ 錯体の反応性を Fig. 2 にまとめる。 $\mathrm{L}_{6} \mathrm{Mn}_{4} \mathrm{O}_{4}$ 錯体は $\mathrm{CH}_{2} \mathrm{Cl}_{2}$ 溶液中で水素原 子供与体であるフェノチアジンとの反応により水二分子 を遊離し、 $\mathrm{L}_{6} \mathrm{Mn}_{4} \mathrm{O}_{2}$ および $\left[\mathrm{L}_{5} \mathrm{Mn}_{4} \mathrm{O}_{2}\right]^{+}$種を生成する ${ }^{27)}$ 。 この結果は $\mathrm{Mn}_{4} \mathrm{O}_{4}$ 核のオキソが還元的に水分子に変換 可能であることを示す。一方、気相系で $\mathrm{L}_{6} \mathrm{Mn}_{4} \mathrm{O}_{4}$ 錯体 に UV 光照射を行うと一つのキレート配位子 $\mathrm{L}$ の光解 離に伴い、 $\mathrm{Mn}_{4} \mathrm{O}_{4}$ 核から酸素分子が選択的に生成した ${ }^{28,}$ 29)。これに対し、 $\mathrm{Mn}^{\mathrm{III}}(\mu-\mathrm{O})_{2} \mathrm{Mn}^{\mathrm{IV}}$ 核を含む比較化合物は、 UV 光照射により非選択的に分解し、酸素分子は生成さ れなかった ${ }^{29)}$ 。これは、 $\mathrm{Mn}_{4} \mathrm{O}_{4}$ 核が酸素分子生成におい て特異的な幾何構造であることを示唆している。一般 的に $\mathrm{Mn}^{\mathrm{III}}(\mu-\mathrm{O}){ }_{2} \mathrm{Mn}^{\mathrm{IV}}$ 核の $\mathrm{Mn}-\mathrm{O}\left(\mu_{2}\right.$-oxo $)$ 結合 $(1.8 \AA)$ に 比べ、 $\mathrm{Mn}_{4} \mathrm{O}_{4}$ 核の $\mathrm{Mn}-\mathrm{O}\left(\mu_{3}\right.$-oxo $)$ 結合 $(1.95 \AA)$ の方が長 いため、酸素原子がよりルーズになり、 $\mathrm{Mn}_{4} \mathrm{O}_{4}$ 核で分子 内 O-O 結合が生成可能になったと考えられる。これら の結果は、 $\mathrm{Mn}_{4} \mathrm{O}_{4}$ 核が水分子と酸素分子に変換可能な中 間体であることを暗示し、Fig. 2 に示されるような水か らの酸素発生触媒サイクルの可能性を提示した。即ち、 $\mathrm{L}_{6} \mathrm{Mn}_{4} \mathrm{O}_{2}$ 核に結合した水二分子が酸化され $\mathrm{L}_{6} \mathrm{Mn}_{4} \mathrm{O}_{4}$ が生 成し、 $\left(\mathrm{L}_{6} \mathrm{Mn}_{4} \mathrm{O}_{4}\right.$ からの水の還元的遊離の逆反応 $)$ キレ

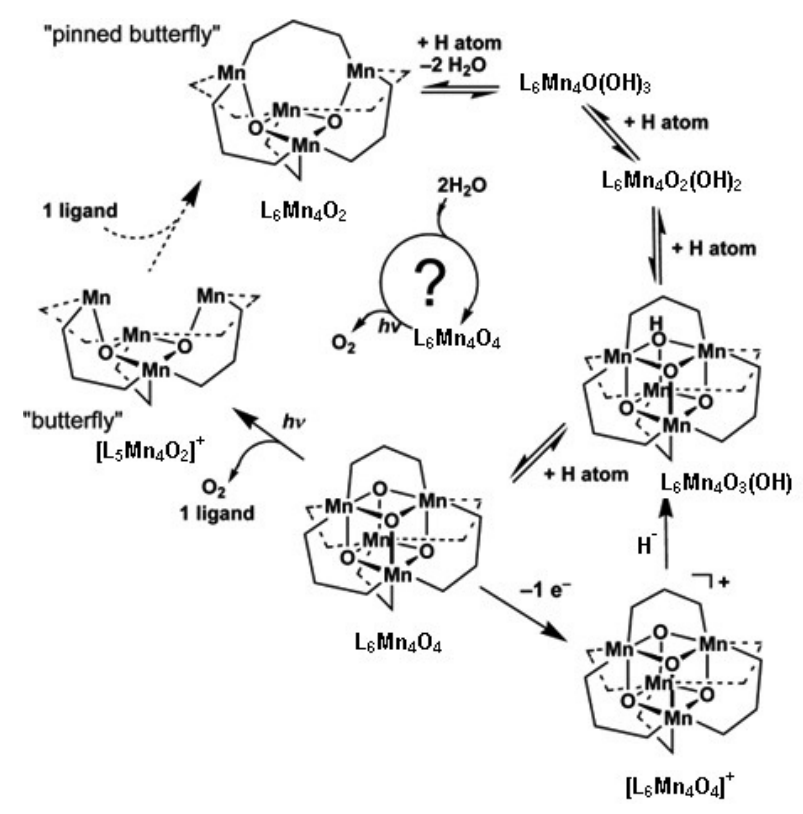

Fig. 2 Reaction pathways and possible photocatalytic cycle for the manganese-oxo cubane, $\mathrm{L}_{6} \mathrm{Mn}_{4} \mathrm{O}_{4}, \mathrm{~L}=$ diphenylphosphinate $\left(\mathrm{Ph}_{2} \mathrm{PO}_{2}^{-}\right)$or bis(4-methoxyphenyl)phosphinate ((4-MeOPh) $\left.{ }_{2} \mathrm{PO}_{2}{ }^{-}\right)$. Reaction pathways include observed reduction reactions of $\mathrm{L}_{6} \mathrm{Mn}_{4} \mathrm{O}_{4}$ and $\left[\mathrm{L}_{6} \mathrm{Mn}_{4} \mathrm{O}_{4}\right]^{+}$in solution and gas-phase photodissociation to yield $\mathrm{O}_{2}$. (Reprinted with permission from Angew. Chem. Int. Ed., 47, 7335 (2008). Copyright $\odot 2008$ WILEYVCH Verlag $\mathrm{GmbH} \&$ Co. KGaA.) 
ート配位子 $\mathrm{L}$ の光解離を伴い $\mathrm{L}_{6} \mathrm{Mn}_{4} \mathrm{O}_{4}$ から酸素が生成 すると期待された。しかし、凝縮系では $\mathrm{L}_{6} \mathrm{Mn}_{4} \mathrm{O}_{4}$ から $\mathrm{L}$ の光解離に伴う酸素発生が困難であったため、この触媒 サイクルを実現するには至らなかった ${ }^{28)}$ 。最近、bis(4methoxylphenyl)phosphonate (L') を有する $\mathrm{L}_{6} \mathrm{Mn}_{4} \mathrm{O}_{4}$ 誘 導体をナフィオン膜に取り込むことにより Fig. 2 の触 媒サイクルに基づいた水の酸化が報告された ${ }^{30-34) 。 一 ~}$ 電子酸化体である $\left[\mathrm{L}_{6}{ }_{6} \mathrm{Mn}_{4} \mathrm{O}_{4}\right]^{+}$をカチオン交換よりナ フィオン膜に取り込み、 $\left[\mathrm{L}_{6}{ }_{6} \mathrm{Mn}_{4} \mathrm{O}_{4}\right]^{+}$分散ナフィオン膜 被覆グラッシーカーボン電極を作成した。1.0 V vs Ag/ $\mathrm{AgCl}$ のバイアス下、0.1 $\mathrm{M} \mathrm{Na}_{2} \mathrm{SO}_{4}$ 水溶液中でこの電極

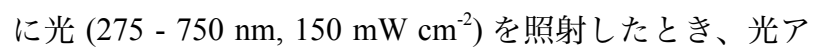
ノード電流が生じた。この光電流は 65 時間後でも $75 \%$ 保持され、65 時間の触媒反応に要した電荷量は $0.163 \mathrm{C}$ で、 $\left[\mathrm{L}_{6}{ }_{6} \mathrm{Mn}_{4} \mathrm{O}_{4}\right]^{+}$(電極上の被覆量 $0.27 \mathrm{nmol}$ ) の TN はお よそ 1000 回と見積もられた。 $\mathrm{H}_{2}{ }^{18} \mathrm{O}$ 溶媒を用いた実験 で、発生酸素の酸素原子源が水であることが示された。

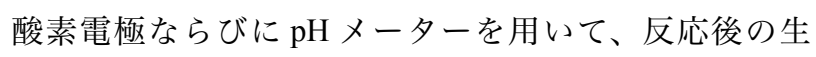
成物として酸素と $\mathrm{H}^{+}$がほぼ化学量論的に生成すること を明らかにした。 $\left[\mathrm{L}_{6}{ }_{6} \mathrm{Mn}_{4} \mathrm{O}_{4}\right]^{+}$分散ナフィオン膜で、気 相系で見られたような L' の光解離を伴う酸素発生が進 行し、“reduced butterfly” $\left[\mathrm{L}_{5}{ }_{5} \mathrm{Mn}_{4} \mathrm{O}_{2}\right]^{2+}$ が生成すると推定 された ${ }^{35)}$ 。 $\left[\mathrm{L}_{5} \mathrm{Mn}_{4} \mathrm{O}_{2}\right]^{2+}$ は有機溶媒中で徐々に高分子化

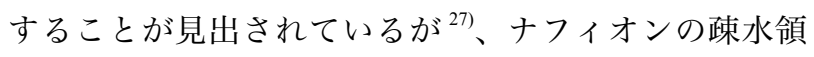
域では安定に存在すると考えられた。 $\left[\mathrm{L}_{5} \mathrm{Mnn}_{4} \mathrm{O}_{2}\right]^{2+}$ の電 気化学的酸化により、L'配位子と水二分子を取り込み、 $\left[\mathrm{L}_{6}{ }_{6} \mathrm{Mn}_{4} \mathrm{O}_{4}\right]^{+}$が生成すると推定された。光エネルギーは、 $\left[\mathrm{L}_{6}{ }_{6} \mathrm{Mn}_{4} \mathrm{O}_{4}\right]^{+}$触媒の活性化に寄与すると考えられた。今後、 活性種の同定と詳細な触媒機構の解明に注目したい。

1,2-フェニレンで連結したマンガンテトラフェニルポ ルフィリン二量体による水の電気化学的酸化が報告され た ${ }^{36)}$ 。酸素発生の中間体として、OH-Mn ${ }^{\mathrm{V}}=\mathrm{O}$ 種 $\left(-\mathrm{OH}^{-}\right.$

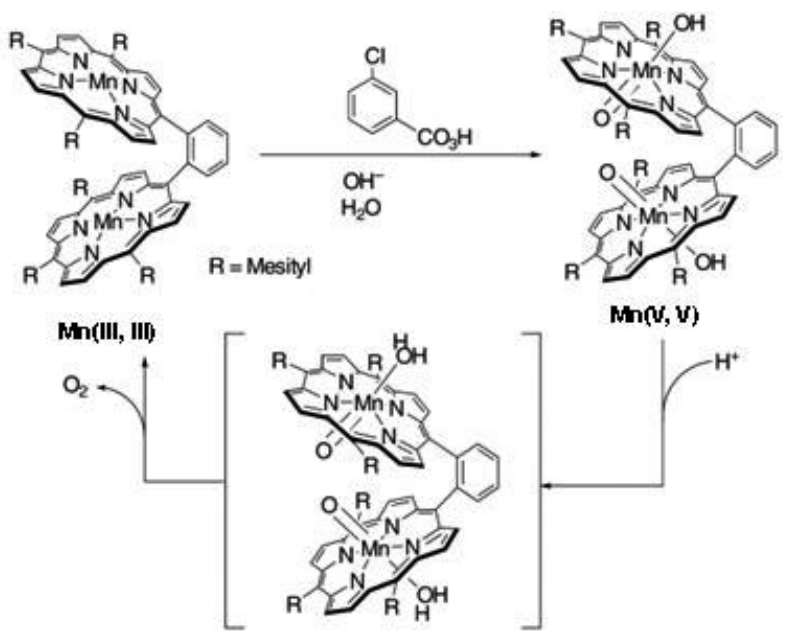

Fig. 3 Structure of the manganese porphyrin dimer and the reaction pathway for $\mathrm{O}_{2}$ formation. (Reprinted with permission from Angew. Chem. Int. Ed., 43, 98 (2004). Copyright @ 2004 WILEYVCH Verlag $\mathrm{GmbH} \&$ Co. KGaA.)
および $=\mathrm{O}$ はアキシャル配位子を示す。）が同定された。 $10 \%$ 水を含む $\mathrm{OH}-\mathrm{Mn}^{\mathrm{V}}=\mathrm{O}$ 種の $\mathrm{CH}_{2} \mathrm{Cl}_{2} / \mathrm{CH}_{3} \mathrm{CN}$ 溶液に卜 リフルオロメタンスルホン酸を加えると、 $\mathrm{Mn}^{\mathrm{IIIIII}}$ 種の 生成を伴い酸素が発生した ${ }^{37}$ 。 $\mathrm{OH}-\mathrm{Mn}^{\mathrm{V}}=\mathrm{O}$ 種のプロト ネーションにより $\mathrm{OH}_{2}-\mathrm{Mn}^{\mathrm{V}}=\mathrm{O}$ 種が生成し、これに水が 攻撃して O-O 結合が形成されると推定された (Fig. 3)。 最近、リン酸基を導入したマンガンテトラフェニルポル フィリン二量体誘導体が合成され、これを電極表面に修 飾することにより水の酸化のための安定な電気触媒とし て働くことが示された ${ }^{38)}$ 。

\section{3. ルテニウム錯体}

1980 年代はじめ、Meyer らにより “blue dimer” 15-17)、 およびその誘導体 ${ }^{39,40)}$ が水の酸化触媒として働くこと が報告された。blue dimerのターンオーバー速度（TOF） および TN は $4.2 \times 10^{-3} \mathrm{~s}^{-1}{ }^{41)}$ および 13.2 回 ${ }^{42)}$ と報告され た。これまで blue dimer の構造、酸化還元特性および水 の酸化触媒機構に関する研究が数多く報告されている が、水の酸化触媒機構に関する統一的な見解は未だ得ら れていない ${ }^{15-17,39-50)}$ 。リン酸基を有する blue dimer 誘導 体、 $\left[\left(\mathrm{PO}_{3} \mathrm{H}_{2} \text {-tpy }\right)\left(\mathrm{H}_{2} \mathrm{O}\right)_{2} \mathrm{Ru}^{\text {III }}(\mu-\mathrm{O}) \mathrm{Ru}^{\mathrm{III}}\left(\mathrm{H}_{2} \mathrm{O}\right)_{2}\left(\mathrm{PO}_{3} \mathrm{H}_{2} \text {-tpy }\right)\right]^{4+}$ $\left(\mathrm{Ru}^{\mathrm{III}}(\mu-\mathrm{O}) \mathrm{Ru}^{\mathrm{III}}\right)\left(\mathrm{PO}_{3} \mathrm{H}_{2}\right.$-tpy = 4'-phosphonato-2,2':6',2”terprydine) が合成され、金属酸化物表面に化学吸着によ つて導入された ${ }^{51)} 。 \mathrm{Ru}^{\mathrm{III}}(\mu-\mathrm{O}) \mathrm{Ru}^{\mathrm{III}}$ 吸着 $\mathrm{ZrO}_{2}$ のサイクリ ックボルタモグラムでは、 $\mathrm{Ru}^{\mathrm{II}}-\mathrm{O}-\mathrm{Ru} \mathrm{II}^{\mathrm{II}} / \mathrm{Ru}^{\mathrm{III}}-\mathrm{O}-\mathrm{Ru} \mathrm{III}^{\mathrm{II}}$ の二 電子過程および $\mathrm{Ru}^{\mathrm{III}}-\mathrm{O}-\mathrm{Ru} \mathrm{u}^{\mathrm{III}} / \mathrm{Ru}^{\mathrm{III}}-\mathrm{O}-\mathrm{Ru}^{\mathrm{IV}}$ のプロトン共 役一電子過程が観察された。 $\mathrm{Ru}^{\mathrm{III}}(\mu-\mathrm{O}) \mathrm{Ru}^{\mathrm{III}}$ 吸着 $\mathrm{ZrO}_{2}$ を 用いて、 $\mathrm{pH}=1$ および $\mathrm{pH}=6$ の条件で水の電気触媒化 学的酸化が行われた。どちらの $\mathrm{pH}$ 条件でも、触媒アノ 一ド電流は 1 時間後に〜 $10 \%$ に減少した。触媒反応に 要した電荷量から換算された $\mathrm{Ru}^{\mathrm{III}}(\mu-\mathrm{O}) \mathrm{Ru} \mathrm{R}^{\mathrm{III}}$ の $\mathrm{TN}$ は $\mathrm{pH}$ $=6$ のとき 2 〜回であった。このように、 $\mathrm{Ru}^{\mathrm{III}}(\mu-\mathrm{O})$ $\mathrm{Ru}^{\mathrm{III}}$ 錯体による水の酸化触媒能が金属酸化物表面に付与 されることが示されたが、今後の課題として頑強な触媒 の開発が重要であることが指摘された ${ }^{51}$ 。

多座ポリピリジル配位子にキレートされた二核 ルテニウム錯体が報告された ${ }^{52-55)}$ 。3,5-bis(2-pyridyl) pyrazolate（bpp）配位子によりキレートされた [(tpy) $\left(\mathrm{H}_{2} \mathrm{O}\right) \mathrm{Ru}^{\mathrm{II}}(\mathrm{bpp}) \mathrm{Ru}^{\mathrm{II}}\left(\mathrm{H}_{2} \mathrm{O}\right)($ tpy $\left.)\right]^{3+}$ 錯体 ${ }^{52}$ お よび 3,6-bis-[6'(1",8"-naphthyrid-2"-yl)-pydid-2'-yl]pyridazine キレート 配位子 $\left(\mathrm{macroN}_{6}\right)$ および クロロ配位子で架橋した二核 ルテニウム錯体 $\left[\mathrm{Ru}_{2}\left(\mathrm{macroN}_{6}\right)(\mathrm{Rpy})_{4} \mathrm{Cl}\right]^{3+}$ 錯体 $\left.{ }^{53}\right)(\mathrm{Rpy}=$ alkylpyridine）が水の酸化触媒活性を示すことが報告さ れた。1,8-bis(2,2':6',2"-terpyridyl)anthracene (btpyan) 配 位子でキレートした $\left[\left(t \mathrm{Bu}_{2} \mathrm{qui}\right)(\mathrm{OH}) \mathrm{Ru}^{\mathrm{II}}(\mathrm{btpyan}) \mathrm{Ru} \mathrm{u}^{\mathrm{II}}(\mathrm{OH})\right.$ $\left.\left(t \mathrm{Bu}_{2} \mathrm{qui}\right)\right]^{2+}$ (btpyan dimer, Fig. 4) $\left(t \mathrm{Bu}_{2} \mathrm{qui}=3,6\right.$-di-tertbutyl-1,2-benzoquinone）が合成された ${ }^{54,55)}$ 。この錯体は、 
ルテニウム中心だけでなく、配位子も酸化還元活性であ るため、両者に水の酸化に必要な酸化力を蓄積できるの が特徴であり、両者の共役に基づく興味深い酸化還元特 性が明らかにされている ${ }^{54,55)}$ 。溶液から btpyan dimer を 析出させた ITO 電極を用いて、 $1.7 \mathrm{~V} \mathrm{vs} \mathrm{Ag} / \mathrm{AgCl}$ で水の 電気触媒化学的酸化が行われ、40 時間で $15.2 \mathrm{ml}$ の酸素 が発生した。そのときのbtpyan dimerの TNは33500回で、 btpyan dimer が安定な水の酸化触媒として働くことが示 された ${ }^{55)}$ 。

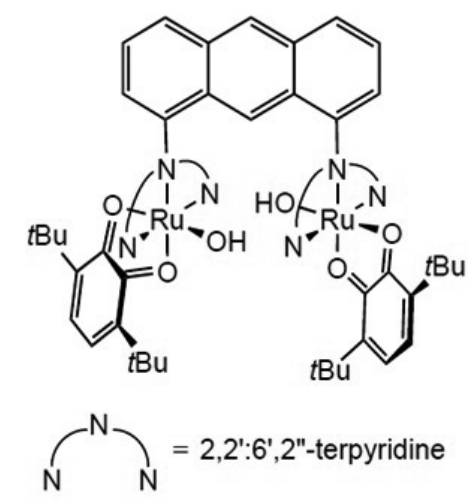

Fig. 4 Structure of Ru btpyan dimer (Reprinted with permission from Angew. Chem. Int. Ed., 39, 1479 (2000). Copyright (c 2000 WILEY-VCH Verlag GmbH \& Co. KGaA.)

単核ルテニウム錯体も水の酸化触媒として働くこと が知られている ${ }^{53,56-63)}$ 。最近、Meyer らは $[\mathrm{Ru}(\mathrm{tpy})(\mathrm{bpm})$ $\left.\left(\mathrm{OH}_{2}\right)\right]^{2+}\left(\mathrm{bpm}=2,2^{\prime}\right.$-bipyrimidine $)$ お よび $[\mathrm{Ru}(\mathrm{tpy})(\mathrm{bpz})$ $\left.\left(\mathrm{OH}_{2}\right)\right]^{2+}(\mathrm{bpz}=2,2$ '-bipyrazine $)$ が水の酸化触媒として働く ことを報告し ${ }^{61)}$ 、単核ルテニウムによる水の酸化触媒機 構を提案した (Fig. 5) ${ }^{61-64)}$ 。 $\mathrm{Ru}^{\mathrm{II}}-\mathrm{OH}_{2}$ (tpy おうよび bpz or bpm 配位子は省略）は 2 電子 2 プロトン過程で $\mathrm{Ru}^{\mathrm{IV}}=\mathrm{O}$ を生成し、さらにもう一電子酸化され、 $\mathrm{Ru}^{\mathrm{v}}=\mathrm{O}$ を生成 する。 $\mathrm{Ru}^{\mathrm{v}}=\mathrm{O}$ は水との反応により過酸化物中間体 $\mathrm{Ru}^{\mathrm{III}}$ $\mathrm{OOH}$ を生成し、さらに一電子酸化された $\mathrm{Ru}^{\mathrm{IV}}-\mathrm{OO}$ を経 て酸素が発生し、同時に水が取り込まれて $\mathrm{Ru}^{\mathrm{II}}-\mathrm{OH}_{2}$ が

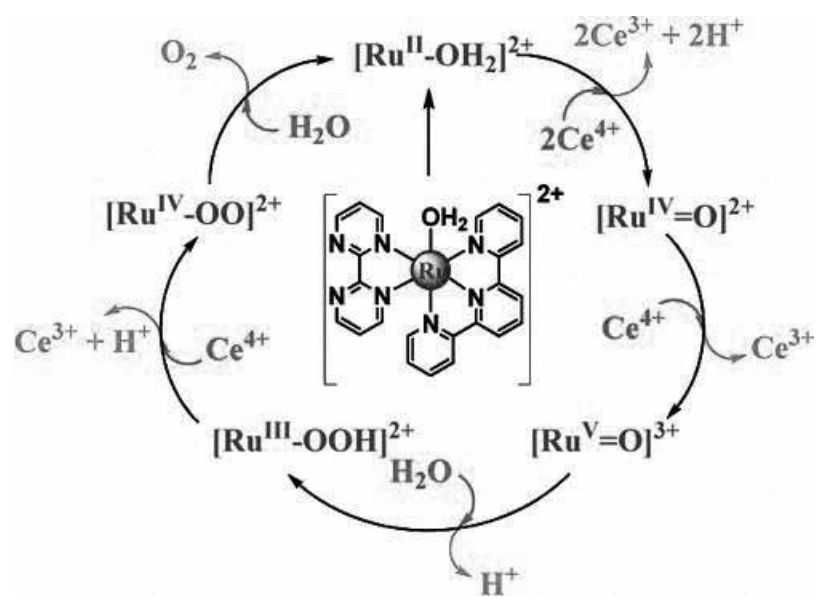

Fig. 5 Mechanism of water oxidation by $\left[\mathrm{Ru}(\mathrm{tpy})(\mathrm{bpm})\left(\mathrm{OH}_{2}\right)\right]^{2+}$ or $\left[\mathrm{Ru}(\mathrm{tpy})(\mathrm{bpz})\left(\mathrm{OH}_{2}\right)\right]^{2+}$ proposed by Meyer. (Reprinted with permission from J. Am. Chem. Soc., 130, 16462 (2008). Copyright 2008 American chemical Society.)
再生すると考えられた ${ }^{61)}$ 。しかし、Ru ${ }^{\mathrm{III}}-\mathrm{OOH}$ おおび $\mathrm{Ru}^{\mathrm{IV}}-\mathrm{OO}$ の同定は不十分で、今後の詳細な研究に注目し たい。tpy 骨格に類似した 2,6-bis(1-methylbenzimidazol2-yl)pyridine (Mebimpy) 配位子を有する $[\mathrm{Ru}($ Mebimpy) (bpy) $\left.\left(\mathrm{OH}_{2}\right)\right]^{2+}$ 誘導体が合成され ${ }^{62)}$ 、水の電気触媒化学的 酸化が報告された ${ }^{65,60)}$ 。さらに、協奏的酸素原子ープロ トン移動による O-O 結合形成機構 ${ }^{677}$ 、有機溶媒中での 水の酸化促進効果 ${ }^{68}$ 、酸化還元メディエーター触媒分子 による電気触媒反応 ${ }^{69}$ など研究が活発に展開されてい る。

Sun らは負電荷配位子を有する単核ルテニウムア コ 錯 体、 $\left[\mathrm{Ru}(\mathrm{bpydc})(\mathrm{pic})_{2}\right]\left(\mathrm{bpydc}=2,2^{\prime}\right.$ '-bipyridine-6,6'dicarboxylate and pic $=4$-picoline) を合成し、水の酸化触 媒として働くことを報告した（Fig. 6） ${ }^{70,71)} 。 \mathrm{Ce}^{\mathrm{IV}}$ 酸化 剂を用いた水の酸化反応で、 $\left[R u(b p y d c)(p i c)_{2}\right]$ の酸素発 生速度は錯体濃度の二次に依存し、二次速度定数 7.83 x $10^{5} \mathrm{M}^{-1} \mathrm{~s}^{-1}$ を与えた。これより、錯体二分子が協同的 に働くことが示唆された。触媒反応中間体と考えられ る $\mathrm{Ru}^{\mathrm{IV}}$ 種が単離され、 $\mathrm{X}$ 線構造解析により水配位を加 えた 7 配位構造を有することが示された（Fig. 6)。これ より、水配位子が触媒活性点になり、分子間で O-O 結 合が形成される機構が示唆された。 $\left[R u(b p y d c)(p i c)_{2}\right]$ 触 媒 / $\left[\mathrm{Ru}(\mathrm{bpy})_{3}\right]^{2+}$ 光増感剤 $/ \mathrm{S}_{2} \mathrm{O}_{8}^{2-}$ または $\left[\mathrm{Co}\left(\mathrm{NH}_{3}\right)_{5} \mathrm{Cl}\right]^{2+}$ 犠牲アクセプター均一水溶液系で、水の光化学的酸 化が報告された ${ }^{72)}$ 。さらに、ナフイオン膜を用いて $\left[\mathrm{Ru}(\mathrm{bpydc})(\mathrm{pic})_{2}\right]$ を色素増感型ナノポーラス $\mathrm{TiO}_{2}$ 電極に 応用し、水の光電気化学的酸化が行わ机た。 $-0.325 \mathrm{~V}$ vs $\mathrm{Ag} / \mathrm{AgCl}$ のバイアス下で水から酸素および水素が発生 することが示された ${ }^{73)}$ 。類似の $\left[\mathrm{Ru}(\mathrm{pydc})(\mathrm{pic})_{3}\right](\mathrm{pydc}=$ 2,6-pyridinedicarboxyliclate) では、酸素発生速度は錯体 濃度の一次に依存し、一分子で働くことが示唆された。 アクア化により pic 配位子の一つが解離した $[\mathrm{Ru}(\mathrm{pydc})$ $\left.(\text { pic })_{2}\left(\mathrm{H}_{2} \mathrm{O}\right)\right]^{+}$が活性種であると推定された。[Ru(pydc) (pic) $)_{3}$ の TOF は $2.3 \times 10^{-1} \mathrm{~s}^{-1}$ と高い值を示した ${ }^{71}$ 。類似 の二核錯体も水の酸化触媒として働くことが示され ${ }^{74)}$ 、

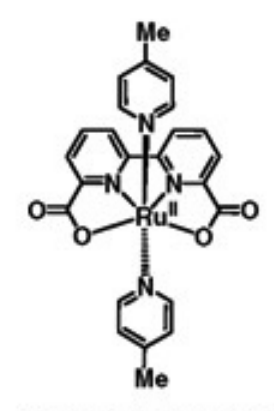

$\left[\mathrm{Ru}(\mathrm{bpydc})(\mathrm{pic})_{2}\right]$

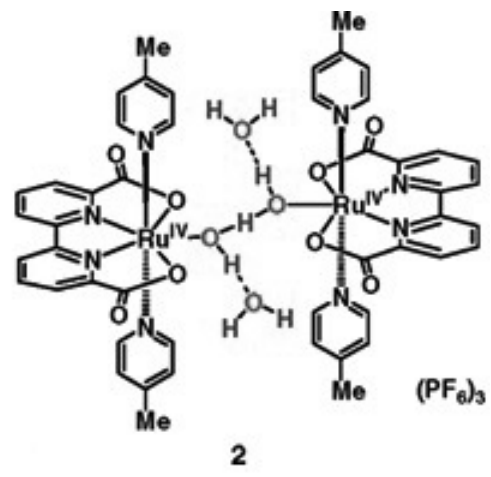

Fig. 6 Structures of $\left[\mathrm{Ru}(\mathrm{bpydc})(\mathrm{pic})_{2}\right]$ and $\mathrm{Ru}^{\mathrm{iv}}$ intermediate. (Reprinted with permission from J. Am. Chem. Soc., 131, 10397 (2009). Copyright 2009 American chemical Society.) 

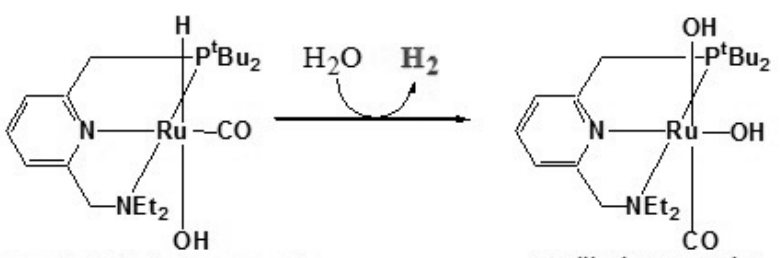

trans-hydrido-hydroxo complex

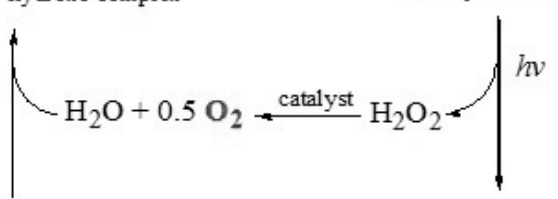

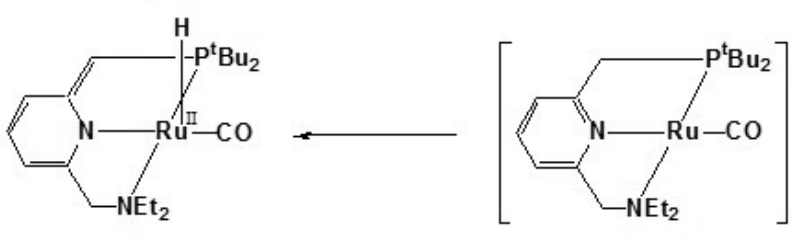

hydrido complex

Fig. 7 Proposed mechanism for consecutive $\mathrm{H}_{2}$ and $\mathrm{O}_{2}$ evolution by a mononuclear ruthenium (II) pincer complex.

$\left[R u(b p y)_{3}\right]^{2+}$ - 光増感系で光化学的酸素発生が報告された 75)

$\mathrm{Ru}$ (II) pincer 錯体による連続的熱駆動水素発生一光 駆動酸素発生による水分解反応が報告された (Fig. 7) ${ }^{76)}$ 。 hydride 錯体は $25{ }^{\circ} \mathrm{C}$ で水と反応して trans-hydridehydroxo 錯体を生成する。 hydride-hydroxo 錯体を水中 で3日間還流することにより、水素発生を伴い cisdihydroxo 錯体が生成した。水素および cis-dihydroxo 錯 体の生成収率はそれぞれ $37 \%$ および 45\%であった。水 または THF 中で cis dihydroxo 錯体に 2 日間光照射（ $\lambda$ $>320 \mathrm{~nm}$ ) したとき、収率 $23 \%$ で酸素が発生した。反 応後の溶液の NMRスペクトルより、未反応の cisdihydroxo 錯体 (収率 33\%) と副生成物 (収率 22\% ) に加 え、trans-hydrido-hydroxo 錯体 (収率 $45 \%$ ) が生成した。 cis dihydroxo 錯体の 2 つの水酸基を ${ }^{18} \mathrm{O}$ でラベルした同 位体 (cis dihydroxo- ${ }^{18} \mathrm{O}^{18} \mathrm{O}$ ) を用いた同様の光化学的酸 素発生実験では、主生成物として ${ }^{36} \mathrm{O}_{2}$ が生成した。cisdihydroxo- ${ }^{18} \mathrm{O}^{18} \mathrm{O}$ と $\mathrm{H}_{2} \mathrm{O}$ 溶媒との間で酸素原子の交換は 観察されなかった。さらに、cis-dihydroxo- ${ }^{16} \mathrm{O}^{16} \mathrm{O}$ と cisdihydroxo- ${ }^{18} \mathrm{O}^{18} \mathrm{O}$ の等量を含む水溶液中で行った同様の 実験では、主生成物として ${ }^{32} \mathrm{O}_{2}$ および ${ }^{36} \mathrm{O}_{2}$ が生成した。 これらの結果より、一つのルテニウム中心上で cis 位の 水酸基の分子内カップリングにより O-O 結合が形成さ れることが示された。光過程で cis-dihydroxo 錯体が過 酸化水素を遊離し、過酸化水素の不均化により酸素分子 と水が生成する機構が推定された。還流下における水素 生成を伴う trans-hydrido-hydroxo 錯体から cis-dihydroxo 錯体の熱的変換と、酸素発生を伴う cis-hydroxo 錯体か ら trans-hydrido hydroxo 錯体への光化学的変換を組み合 わせれば、水の分解サイクルが構築できる。

\section{4. イリジウム錯体}

水の酸化触媒能を有するイリジウム錯体とし て、bis-phenylpyridine 誘導体 $\left(R_{1} R_{2}\right.$ ppy) を有する $\left[\operatorname{Ir}^{\mathrm{III}}\left(\mathrm{R}_{1} \mathrm{R}_{2} \text { ppy }\right)_{2}\left(\mathrm{OH}_{2}\right)_{2}\right]^{+}$錯体（Fig. 8) が報告された ${ }^{77)}$ 。均 一水溶液中 $(10 \mathrm{ml})$ における $\left[\operatorname{Ir}^{\mathrm{III}}\left(\mathrm{R}_{1} \mathrm{R}_{2} \mathrm{ppy}\right)_{2}\left(\mathrm{OH}_{2}\right)_{2}\right]^{+}$錯体 $(3 \mu \mathrm{mol})$ と $\mathrm{Ce}^{\mathrm{IV}}$ 酸化剤 $(1720 \mu \mathrm{mol})$ との反応により酸素 が発生した。初期における $\left[\mathrm{Ir}^{\mathrm{III}}\left(\mathrm{R}_{1} \mathrm{R}_{2} \mathrm{ppy}\right)_{2}\left(\mathrm{OH}_{2}\right)_{2}\right]^{+}$錯体 の TOF は $0.93 \sim 4.6 \times 10^{-3} \mathrm{~s}^{-1}$ であった。水 $10 \mathrm{ml}$ 中に 0.5 $\mu \mathrm{mol}\left[\operatorname{Ir}^{\mathrm{III}}\left(\mathrm{R}_{1} \mathrm{R}_{2} \mathrm{ppy}\right)_{2}\left(\mathrm{OH}_{2}\right)_{2}\right]^{+} 、 15000 \mu \mathrm{mol} \mathrm{Ce} \mathrm{IIV}^{\mathrm{IV}}$ を含む条件 で、 $\left[\operatorname{Ir}^{\mathrm{III}}\left(\mathrm{R}_{1} \mathrm{R}_{2} \mathrm{ppy}\right)_{2}\left(\mathrm{OH}_{2}\right)_{2}\right]^{+}$錯体の TN は 7 日間で 2270 2760 回であった。比較の $\left[\operatorname{Ir}^{\mathrm{III}}\left(\mathrm{R}_{1} \mathrm{R}_{2} \mathrm{ppy}\right)_{2}(\mathrm{bpy})\right]^{+}$錯体が水 の酸化触媒活性を示さなかったことより、水の酸化にお いて $\left[\operatorname{Ir}^{\mathrm{III}}\left(\mathrm{R}_{1} \mathrm{R}_{2} \mathrm{ppy}\right)_{2}\left(\mathrm{OH}_{2}\right)_{2}\right]^{+}$錯体のビスアコ構造が重要で あると結論付けられた。しかし、 $\left[\operatorname{Ir}^{\mathrm{III}}\left(\mathrm{R}_{1} \mathrm{R}_{2} \mathrm{ppy}\right)_{2}\left(\mathrm{OH}_{2}\right)_{2}\right]^{+}$ 錯体の構造変化も確認され、複数の活性種が存在するこ とも報告されている。

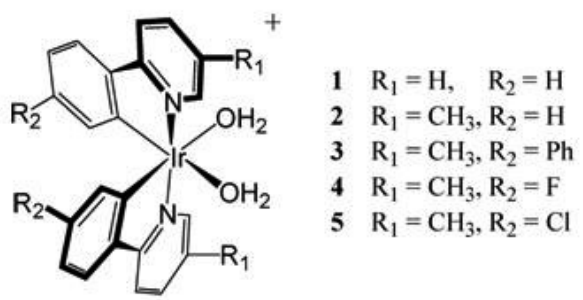

Fig. 8 Structure of $\left[I r^{\prime \prime \prime}\left(\mathrm{R}_{1} \mathrm{R}_{2} \mathrm{ppy}\right)_{2}\left(\mathrm{OH}_{2}\right)_{2}\right]^{+}$. (Reprinted with permission from J. Am. Chem. Soc., 130, 210 (2008). Copyright 2008 American chemical Society.)

1,2,3,4,5-pentamethylcyclopentadiene（Cp*）を有するイ リジウム錯体 $[\mathrm{Cp} * \operatorname{IrCl}(\mathrm{ppy})]$ (ppy = 2-phenylpyridine) が合 成され、高活性な水の酸化触媒として働くことが報告さ れた ${ }^{78,79)}$ 。 $\mathrm{Ce}^{\mathrm{IV}}$ 酸化剂を用いたときの TOF は $9.1 \times 10^{-1}$ $\mathrm{s}^{-1}$ と高い值を示した ${ }^{79)}$ 。類似の $\mathrm{Cp}^{*}$ イリジウム錯体が 別の研究グループから報告された ${ }^{80)}$ 。トリアゾリデンキ レート配位子 1、 $\mathrm{Ag}_{2} \mathrm{O}$ および $\left[\mathrm{Cp}^{*} \mathrm{IrCl}_{2}\right]_{2}$ を含むアセト

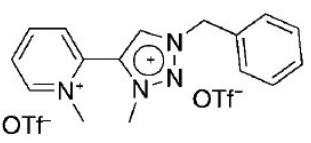

$\mid \begin{aligned} & \mathrm{Ag}_{2} \mathrm{O},\left[\left\{\mathrm{Cp}^{*} \mid r \mathrm{Cl}_{2}\right\}_{2}\right] \\ & \mathrm{MeCN}\end{aligned}$

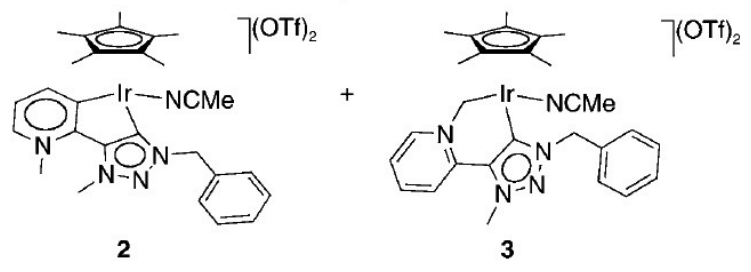

Fig. 9 Synthesis of complexes 2 and 3. (Reprinted with permission from Angew. Chem. Int. Ed., 49, 9765 (2010). Copyright $\odot 2010$ WILEY-VCH Verlag GmbH \& Co. KGaA.) 
ニトリル水溶液を還流することにより二種のトリアゾリ デンイリジウム錯体 2 および 3 を合成・単離された（Fig. 9) ${ }^{80)}$ 。2 および 3 の TOF はそれぞれ $4.2 \times 10^{-2} \mathrm{~s}^{-1}$ およ゙ $8.6 \times 10^{-2} \mathrm{~s}^{-1}$ であった。両錯体ともに $\mathrm{Ce}^{\mathrm{IV}}$ 酸化剂大過㮃 の条件下 $\left(0.2 \mu \mathrm{mol}\right.$ 触媒、 $10 \mathrm{mmol} \mathrm{C \textrm {C } ^ { \mathrm { IV } } )}$ で $\mathrm{Ce}^{\mathrm{IV}}$ に対し て化学量論的に酸素を発生することが示された。2 およ び 3 の最大 TOF は 10000 および 8350 回に達した ${ }^{80)}$ 。

\section{5. ポリオキソメタレート錯体}

最近、水中における $\left[\gamma-\mathrm{SiW}_{10} \mathrm{O}_{36}\right]^{8-}$ と $\mathrm{Ru}_{2} \mathrm{OCl}_{10}{ }^{4-}$ との反 応から $\mathrm{Ru}_{4}(\mathrm{IV})$-oxo 核を有するポリオキソメタレート錯 体 $\mathrm{Cs}_{10}\left[\mathrm{Ru}_{4} \mathrm{O}_{4}(\mathrm{OH})_{2}\left(\mathrm{H}_{2} \mathrm{O}\right)_{4}\left(\gamma-\mathrm{SiW}_{10} \mathrm{O}_{36}\right)_{2}\right]\left(\mathrm{POM}-\mathrm{Ru}_{4} \mathrm{O}_{4}\right)$ が 合成された (Fig. 10） ${ }^{81)}$ 。時期を同じくして、別の研究 グループから異なる合成法より同様の錯体が合成された ${ }^{82)}$ 。 $\mathrm{Ce}^{\mathrm{IV}}{ }^{81)}$ または $\left[\mathrm{Ru}(\mathrm{bpy})_{3}\right]^{3+}{ }^{82)}$ 酸化剂を用いて POM$\mathrm{Ru}_{4} \mathrm{O}_{4}$ の均一系水の酸化触媒反応が研究され、どちら の酸化剂を用いた場合でも $\mathrm{POM}-\mathrm{Ru}_{4} \mathrm{O}_{4}$ は水の酸化触媒 として働くことが示された。 $\mathrm{Ce}^{\mathrm{IV}}$ 酸化剤を用いた系で は、 $\mathrm{pH}=0.6 、 20{ }^{\circ} \mathrm{C}$ の条件で $4.3 \mu \mathrm{mol} \mathrm{POM}-\mathrm{Ru}_{4} \mathrm{O}_{4}$ と $1720 \mu \mathrm{mol}$ of $\mathrm{Ce}^{\mathrm{IV}}$ との反応で酸素発生は 2 時間で頭打ち し、385 $\mu \mathrm{mol}$ の酸素が発生した ${ }^{81)}$ 。これは $\mathrm{Ce}^{\mathrm{IV}}$ に対し て収率 $90 \%$ に対応し、POM- $\mathrm{Ru}_{4} \mathrm{O}_{4}$ の $\mathrm{TN}$ は 90 回であっ た。酸素発生の初期速度は $\mathrm{POM}-\mathrm{Ru}_{4} \mathrm{O}_{4}$ 濃度とともに直 線的に増加し、その直線の傾きから酸素発生の擬一次 速度定数は $9.92 \times 10^{-3} \mathrm{~s}^{-1}$ と算出された $(0.045-1.45 \mu \mathrm{mol}$ $\mathrm{POM}-\mathrm{Ru}_{4} \mathrm{O}_{4}, 10.9 \mathrm{mmol} \mathrm{Ce} \mathrm{IV}^{\mathrm{IV}}$ の条件)。赤外分光スペクト ルおよびラマン分光スペクトル測定より、 $\mathrm{Ce}^{\mathrm{IV}}$ との反 応後 $\mathrm{POM}-\mathrm{Ru}_{4} \mathrm{O}_{4}$ 触媒の構造変化がないことが示された。 $\left[\mathrm{Ru}(\mathrm{bpy})_{3}\right]^{3+}$ 酸化剂を用いた系では、 $10 \mu \mathrm{M}(0.1 \mu \mathrm{mol})$

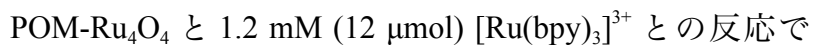
$1.78 \mu \mathrm{mol}$ 酸素および $10.7 \mu \mathrm{mol}\left[\mathrm{Ru}(\mathrm{bpy})_{3}\right]^{2+}$ が生成した。 生成収率は $\left[\mathrm{Ru}(\mathrm{bpy})_{3}\right]^{3+}$ に対してそれぞれ $60 \%$ おび 90

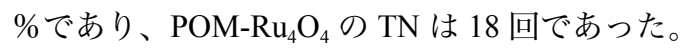

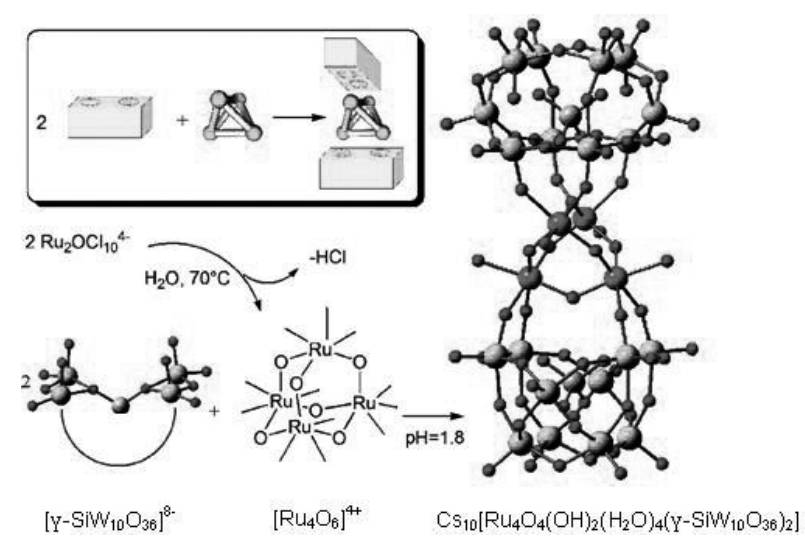

Fig. 10 Formation scheme of $\mathrm{Cs}_{10}\left[\mathrm{Ru}_{4} \mathrm{O}_{4}(\mathrm{OH})_{2}\left(\mathrm{H}_{2} \mathrm{O}\right)_{4}(r\right.$ $\left.\left.-\mathrm{SiW}_{10} \mathrm{O}_{36}\right)_{2}\right]\left(\mathrm{POM}-\mathrm{Ru}_{4} \mathrm{O}_{4}\right)$. (Reprinted with permission from J. Am. Chem. Soc., 130, 5006 (2008). Copyright 2008 American chemical Society.)

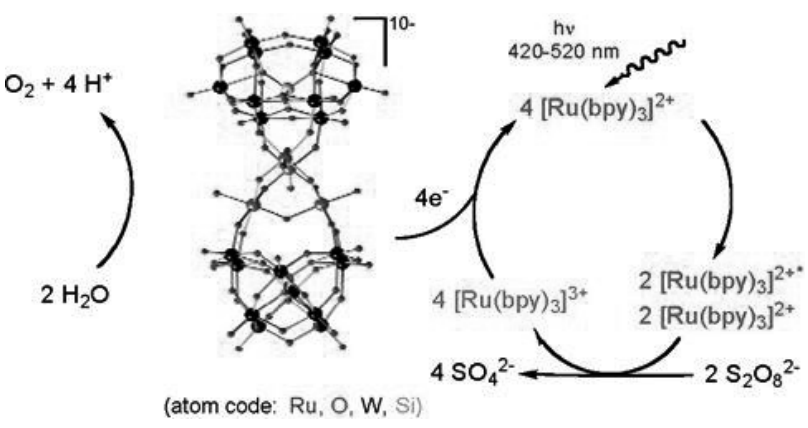

Fig. 11 Reaction scheme of light driven catalytic water oxidation by the POM- $\mathrm{Ru}_{4} \mathrm{O}_{4}$ using $\left[\mathrm{Ru}(\mathrm{bpy})_{3}\right]^{2+}$ and $\mathrm{S}_{2} \mathrm{O}_{8}{ }^{2-}$ ions as a photosensitizer and a sacrificial electron acceptor, respectively. (Reprinted with permission from J. Am. Chem. Soc., 131, 7522 (2009). Copyright 2009 American chemical Society.)

$\mathrm{POM}-\mathrm{Ru}_{4} \mathrm{O}_{4}$ 触媒 $/\left[\mathrm{Ru}(\mathrm{bpy})_{3}\right]^{2+}$ 光増感剂 $/ \mathrm{S}_{2} \mathrm{O}_{8}{ }^{2-}$ 犠牲 アクセプター系で、水の光化学的酸化が報告された (Fig. 11) ${ }^{83)}$ 。 $1.0 \mathrm{mM}(8 \mu \mathrm{mol})\left[\mathrm{Ru}(\mathrm{bpy})_{3}\right]^{2+} 、 5 \mathrm{mM}(40 \mu \mathrm{mol})$ $\mathrm{Na}_{2} \mathrm{~S}_{2} \mathrm{O}_{8}$ および $5.0 \mu \mathrm{M}(40 \mathrm{nmol}) \mathrm{POM}-\mathrm{Ru}_{4} \mathrm{O}_{4}$ 触媒を含む $20 \mathrm{mM}(160 \mu \mathrm{mol})$ リン酸バッファー溶液 $(8 \mathrm{~mL})$ に 420 $520 \mathrm{~nm}$ の可視光 $\left(28 \mathrm{~mW} \mathrm{~cm}{ }^{-2}\right)$ を 35 分間照射したとき、 $7.2 \mu \mathrm{mol}$ の酸素が生成し、同時に $38 \mu \mathrm{mol}$ の $\mathrm{Na}_{2} \mathrm{~S}_{2} \mathrm{O}_{8}$ が 消費された。このときの $\mathrm{POM}^{-\mathrm{Ru}_{4} \mathrm{O}_{4}}$ の $\mathrm{TN}$ は 180 回 で、初期の TOF は $8 \times 10^{-2} \mathrm{~s}^{-1}$ であり、 $\mathrm{Na}_{2} \mathrm{~S}_{2} \mathrm{O}_{8}$ 二当量に 対する酸素の生成収率は $38 \%$ であった。本系における 光酸素発生効率は、主として $\left[\mathrm{Ru}(\mathrm{bpy})_{3}\right]^{3+}$ の光生成量子 収率 $(44 \%)$ および $\mathrm{POM}-\mathrm{Ru}_{4} \mathrm{O}_{4}$ による酸素生成収率に起 因すると考えられ、 $\left[\mathrm{Ru}(\mathrm{bpy})_{3}\right]^{3+}$ の光生成量子収率の向 上が全体の光酸素発生効率の向上につながると指摘さ れた。最近、高価なルテニウム元素の変わりに $\mathrm{Co}_{4} \mathrm{O}_{4}$ 核を有するポリオキソメタレート均一触媒が合成され、 $\left[\mathrm{Ru}(\mathrm{bpy})_{3}\right]^{2+}$ 光増感剤および $\mathrm{S}_{2} \mathrm{O}_{8}{ }^{2-}$ 犠牲アクセプターを含 む光化学系で $\mathrm{TOF}=5 \mathrm{~s}^{-1}$ を与えることが報告された ${ }^{84)}$ 。

\section{6. まとめと展望}

本総説では、水の酸化分子触媒に関する最近の主な研 究例をまとめた。錯体触媒は、その中心金属だけでなく、 多様な配位子および反応場により活性や機構が変化す る。錯体触媒の研究を系統的に実施して水の酸化触媒機 能の発現における重要因子を見出すと共に、安定性およ び活性の向上を目指した分子設計への挑戦は非常に重要 であることは言うまでもない。しかし、エネルギー・環 境問題の深刻さは深まる一途であることを鑑みると、人 工光合成への道すじを意識した研究が肝要であると思わ れる。分子触媒だけでなく、金属・金属酸化物などの微 粒子および電極表面などの界面機能にも目を向け、それ らの活性、機構および応用方法などを比較することが重 要と思われる。その比較の中で、錯体化学の重要性が再 認識されると期待している。 


\section{文献}

1) V. K. Yachandra, K. Sauer, M. P. Klein, Chem. Rev., 96, 2927 (1996).

2) J. P. McEvoy, G. W. Brudvig, Chem. Rev., 106, 4455 (2006).

3) J. Dasgupta, G. M. Ananyev, G. C. Dismukes, Coord. Chem. Rev., 252, 347 (2008).

4) N. Kamiya, J.-R. Shen, Proc. Natl. Acad. Sci. U. S. A., 100, 98 (2003).

5) K. N. Ferreira, T. M. Iverson, K. Maghlaoui, J. Barber, S. Iwata, Science, 303, 1831 (2004).

6) B. Loll, J. Kern, W. Saenger, A. Zouni, J. Biesiadka, Nature, 438, 1040 (2005).

7) N. S. Lewis, D. G. Nocera, Proc. Natl. Acad. Sci. U. S. A., 103, 15729 (2006).

8) T. J. Meyer, Acc. Chem. Res., 22, 163 (1989).

9) J. H. Alstrum-Acevedo, M. K. Brennaman, T. J. Meyer, Inorg. Chem., 44, 6802 (2005).

10) R. Manchanda, G. W. Brudvig, R. H. Crabtree, Coord. Chem. Rev., 144, 1 (1995).

11) W. Ruettinger, G. C. Dismukes, Chem. Rev., 97, 1 (1997).

12) M. Yagi, M. Kaneko, Chem. Rev., 101, 21 (2001).

13) M. Yagi, A. Syouji, S. Yamada, M. Komi, H. Yamazaki, S. Tajima, Photochem. Photobiol. Sci., 8, 139 (2009).

14) H. Yamazaki, A. Shouji, M. Kajita, M. Yagi, Coord. Chem. Rev., 254, 2483 (2010).

15) S. W. Gersten, G. J. Samuels, T. J. Meyer, J. Am. Chem. Soc., 104, 4029 (1982).

16) F. Liu, J. J. Concepcion, J. W. Jurss, T. Cardolaccia, J. L. Templeton, T. J. Meyer, Inorg. Chem., 47, 1727 (2008).

17) J. K. Hurst, J. L. Cape, A. E. Clark, S. Das, C. Qin, Inorg. Chem., 47, 1753 (2008).

18) J. Limburg, J. S. Vrettos, L. M. Liable-Sands, A. L. Rheingold, R. H. Crabtree, G. W. Brudvig, Science, 283, 1524 (1999).

19) J. Limburg, J. S. Vrettos, H. Y. Chen, J. C. de Paula, R. H. Crabtree, G. W. Brudvig, J. Am. Chem. Soc., 123, 423 (2001).

20) R. Tagore, H. Chen, H. Zhang, R. H. Crabtree, G. W. Brudvig, Inorg. Chim. Acta, 360, 2983 (2007).

21) M. Yagi, K. Narita, J. Am. Chem. Soc., 126, 8084 (2004).

22) P. Kurz, G. Berggren, M. F. Anderlund, S. Styring, Dalton Trans., 4258 (2007).

23) K. Narita, T. Kuwabara, K. Sone, K. Shimizu, M. Yagi, J. Phys. Chem. B, 110, 23107 (2006).

24) M. Yagi, K. Narita, S. Maruyama, K. Sone, T. Kuwabara, K.-i. Shimizu, Biochim. Biophys. Acta Bioenerg., 1767, 660 (2007).

25) M. Yagi, M. Toda, S. Yamada, H. Yamazaki, Chem. Commun., 46, 8594 (2010).

26) W. F. Ruettinger, C. Campana, G. C. Dismukes, J. Am. Chem. Soc., 119, 6670 (1997)

27) W. Ruettinger, G. C. Dismukes, Inorg. Chem., 39, 1021 (2000).

28) W. Ruettinger, M. Yagi, K. Wolf, S. Bernasek, G. C. Dismukes, J. Am. Chem. Soc., 122, 10353 (2000).

29) M. Yagi, K. V. Wolf, P. J. Baesjou, S. L. Bernasek, G. C. Dismukes, Angew. Chem. Int. Ed., 40, 2925 (2001).

30) R. Brimblecombe, G. F. Swiegers, G. C. Dismukes, L. Spiccia, Angew. Chem. Int. Ed., 47, 7335 (2008).

31) R. Brimblecombe, D. R. J. Kolling, A. M. Bond, G. C. Dismukes, G. F. Swiegers, L. Spiccia, Inorg. Chem., 48, 7269 (2009).

32) R. Brimblecombe, A. M. Bond, G. C. Dismukes, G. F. Swiegers,
L. Spiccia, Phys. Chem. Chem. Phys., 11, 6441 (2009).

33) G. E. Swiegers, J. H. Huang, R. Brimblecombe, J. Chen, G. C. Dismukes, U. T. Mueller-Westerhoff, L. Spiccia, G. G. Wallace, Chem. Eur. J., 15, 4746 (2009).

34) G. C. Dismukes, R. Brimblecombe, G. A. N. Felton, R. S. Pryadun, J. E. Sheats, L. Spiccia, G. F. Swiegers, Acc. Chem. Res., 42, 1935 (2009).

35) J.-Z. Wu, F. De Angelis, T. G. Carrell, G. P. A. Yap, J. Sheats, R. Car, G. C. Dismukes, Inorg. Chem., 45, 189 (2006).

36) Y. Naruta, M. Sasayama, T. Sasaki, Angew. Chem. Int. Ed. Engl., 33, 1839 (1994).

37) Y. Shimazaki, T. Nagano, H. Takesue, B.-H. Ye, F. Tani, Y. Naruta, Angew. Chem. Int. Ed., 43, 98 (2004).

38) Y. Naruta, personal communication, 2010.

39) F. P. Rotzinger, S. Munavalli, P. Comte, J. K. Hurst, M. Graetzel, F.-J. Pern, A. J. Frank, J. Am. Chem. Soc., 109, 6619 (1987).

40) P. Comte, M. K. Nazeeruddin, F. P. Rotzinger, A. J. Frank, M. Graetzel, J. Mol. Catal., 52, 63 (1989).

41) K. Nagoshi, S. Yamashita, M. Yagi, M. Kaneko, J. Mol. Catal. A: Chem., 144, 71 (1999).

42) J. P. Collin, J. P. Sauvage, Inorg. Chem., 25, 135 (1986).

43) T. J. Meyer, M. H. V. Huynh, Inorg. Chem., 42, 8140 (2003).

44) D. Geselowitz, T. J. Meyer, Inorg. Chem., 29, 3894 (1990).

45) J. A. Gilbert, D. S. Eggleston, W. R. Murphy, D. A. Geselowitz, S. W. Gersten, D. J. Hodgson, T. J. Meyer, J. Am. Chem. Soc., 107, 3855 (1985).

46) C. W. Chronister, R. A. Binstead, J. F. Ni, T. J. Meyer, Inorg. Chem., 36, 3814 (1997).

47) R. A. Binstead, C. W. Chronister, J. F. Ni, C. M. Hartshorn, T. J. Meyer, J. Am. Chem. Soc., 122, 8464 (2000).

48) H. Yamada, J. K. Hurst, J. Am. Chem. Soc., 122, 5303 (2000).

49) Y. Lei, J. K. Hurst, Inorg. Chim. Acta, 226, 179 (1994).

50) H. Yamada, W. F. Siems, T. Koike, J. K. Hurst, J. Am. Chem. Soc., 126, 9786 (2004).

51) F. Liu, T. Cardolaccia, B. J. Hornstein, J. R. Schoonover, T. J. Meyer, J. Am. Chem. Soc., 129, 2446 (2007).

52) C. Sens, I. Romero, M. Rodriguez, A. Llobet, T. Parella, J. BenetBuchholz, J. Am. Chem. Soc., 126, 7798 (2004).

53) R. Zong, R. P. Thummel, J. Am. Chem. Soc., 127, 12802 (2005).

54) T. Wada, K. Tsuge, K. Tanaka, Angew. Chem. Int. Ed., 39, 1479 (2000).

55) T. Wada, K. Tsuge, K. Tanaka, Inorg. Chem., 40, 329 (2001).

56) N. C. Pramanik, S. Bhattacharya, Transition Met. Chem., 22, 524 (1997).

57) M. Yagi, N. Sukegawa, M. Kaneko, J. Phys. Chem. B, 104, 4111 (2000).

58) M. Yagi, S. Tajima, M. Komi, H. Yamazaki, Dalton Trans., 40, 3802, (2011).

59) D. J. Wasylenko, C. Ganesamoorthy, B. D. Koivisto, M. A. Henderson, C. P. Berlinguette, Inorg. Chem., 49, 2202 (2010).

60) S. Masaoka, K. Sakai, Chem. Lett., 38, 182 (2009).

61) J. J. Concepcion, J. W. Jurss, J. L. Templeton, T. J. Meyer, J. Am. Chem. Soc., 130, 16462 (2008).

62) J. J. Concepcion, J. W. Jurss, M. R. Norris, Z. F. Chen, J. L. Templeton, T. J. Meyer, Inorg. Chem., 49, 1277 (2010).

63) J. J. Concepcion, M.-K. Tsai, J. T. Muckerman, T. J. Meyer, J. Am. Chem. Soc., 132, 1545 (2010).

64) J. J. Concepcion, J. W. Jurss, M. K. Brennaman, P. G. Hoertz, A. O. T. Patrocinio, N. Y. M. Iha, J. L. Templeton, T. J. Meyer, Acc. Chem. Res., 42, 1954 (2009). 
65) Z. F. Chen, J. J. Concepcion, J. W. Jurss, T. J. Meyer, J. Am. Chem. Soc., 131, 15580 (2009).

66) Z. F. Chen, J. J. Concepcion, J. F. Hull, P. G. Hoertz, T. J. Meyer, Dalton Trans., 39, 6950 (2010).

67) Z. F. Chen, J. J. Concepcion, X. Q. Hu, W. T. Yang, P. G. Hoertz, T. J. Meyer, Proc. Natl. Acad. Sci. U. S. A., 107, 7225 (2010).

68) Z. Chen, J. J. Concepcion, H. Luo, J. F. Hull, A. Paul, T. J. Meyer, J. Am. Chem. Soc., 132, 17670 (2010).

69) J. J. Concepcion, J. W. Jurss, P. G. Hoertz, T. J. Meyer, Angew. Chem. Int. Ed., 48, 9473 (2009).

70) L. Duan, A. Fischer, Y. Xu, L. Sun, J. Am. Chem. Soc., 131, 10397 (2009).

71) L. Duan, Y. Xu, M. Gorlov, L. Tong, S. Andersson, L. Sun, Chem. Eur. J., 16, 4659 (2010).

72) L. Duan, Y. Xu, P. Zhang, M. Wang, L. Sun, Inorg. Chem., 49, 209 (2009).

73) L. Li, L. Duan, Y. Xu, M. Gorlov, A. Hagfeldt, L. Sun, Chem. Commun., 46, 7307 (2010).

74) Y. Xu, T. Aakermark, V. Gyollai, D. Zou, L. Eriksson, L. Duan, R. Zhang, B. Aakermark, L. Sun, Inorg. Chem., 48, 2717 (2009).

75) Y. Xu, L. Duan, L. Tong, B. Akermark, L. Sun, Chem. Commun., 46, 6506 (2010).

76) S. W. Kohl, L. Weiner, L. Schwartsburd, L. Konstantinovski, L. J.
W. Shimon, Y. Ben-David, M. A. Iron, D. Milstein, Science, 324, 74 (2009).

77) N. D. McDaniel, F. J. Coughlin, L. L. Tinker, S. Bernhard, J. Am. Chem. Soc., 130, 210 (2008).

78) J. D. Blakemore, N. D. Schley, D. Balcells, J. F. Hull, G. W. Olack, C. D. Incarvito, O. Eisenstein, G. W. Brudvig, R. H. Crabtree, J. Am. Chem. Soc., 132, 16017 (2010).

79) J. F. Hull, D. Balcells, J. D. Blakemore, C. D. Incarvito, O. Eisenstein, G. W. Brudvig, R. H. Crabtree, J. Am. Chem. Soc., 131, 8730 (2009).

80) R. Lalrempuia, N. D. McDaniel, H. Mueller-Bunz, S. Bernhard, M. Albrecht, Angew. Chem. Int. Ed., 49, 9765 (2010).

81) A. Sartorel, M. Carraro, G. Scorrano, R. De Zorzi, S. Geremia, N. D. McDaniel, S. Bernhard, M. Bonchio, J. Am. Chem. Soc., 130, 5006 (2008).

82) Y. V. Geletii, B. Botar, P. Koegerler, D. A. Hillesheim, D. G. Musaev, C. L. Hill, Angew. Chem. Int. Ed., 47, 3896 (2008).

83) Y. V. Geletii, Z. Huang, Y. Hou, D. G. Musaev, T. Lian, C. L. Hill, J. Am. Chem. Soc., 131, 7522 (2009).

84) Q. Yin, J. M. Tan, C. Besson, Y. V. Geletii, D. G. Musaev, A. E. Kuznetsov, Z. Luo, K. I. Hardcastle, C. L. Hill, Science, 342, 342 (2010).

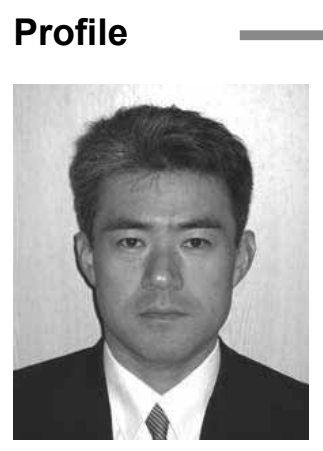

\section{八木 政行}

新潟大学大学院自然科学研究科教授 工学博士

[ 経歴 ] 1996 年埼玉大学大学院理工学研究科博士後期課程修了、1996 年新潟大学教育学部 助手、1997 年新潟大学教育学部助教授、1999-2001 年日本学術振興会海外特別研究員、プ リンストン大学化学科客員研究員、2003 新潟大学超域研究機構助教授併任、2009 年より現職。 2009 年独立行政法人科学技術振興機構（JST）さきがけ研究員併任。

[ 専門] 錯体化学、電気化学、光化学 